\title{
The Role of Teachers as Motivators and Their Influence on Learning Outcomes (Analysis Study of Class 1D Santri at LPI Mudi Putri Mesjid Raya Samalanga, Bireuen Regency)
}

\author{
Tgk Armis ${ }^{1}$, Muliani $^{2}$, Izzatul Mauliza ${ }^{3}$ \\ 1,2,3STIS Dayah Amal, Indonesia
}

\begin{abstract}
:
In the field of education, the teacher is a very important role in teaching and learning, in order to educate humans from stupidity to become intelligent humans, and educate humans from failure to become successful and talented humans. This paper deals with the role of teachers as motivators and their influence on learning outcomes (analysis study of class 1D Santri at LPI Mudi Putri Mesjid Raya Samalanga, Bireuen Regency). The type of research method that researchers use in this study is qualitative methods. This study found that in guarding learning activities, teachers are not just directing various learning materials as has been implemented by the education curriculum section at Dayah MUDI Putri Mesjid Raya Samalanga, Bireuen Regency, but the teacher's job is to always provide motivation in learning objectives, and provide advice that can soften the hearts of students. This study also found that the factors that influence students' learning outcomes both inside and outside the classroom, are not consistent in learning goals.
\end{abstract}

Keywords:

teachers; motivation; learning outcomes; student

\section{Introduction}

In the world of education, teachers are the first step in achieving success with teachers, humans will know everything they want, both in terms of broad knowledge, technology, and other information. In the field of education, the teacher is a very important role in teaching and learning, in order to educate humans from stupidity to become intelligent humans, and educate humans from failure to become successful and talented humans.

In law no. 20 of 2003 concerning the National Education System states that education is a conscious and planned effort to create a learning atmosphere and learning process so that students actively develop their potential to have spiritual, religious, self-control, personality, intelligence, noble character and skills needed by himself, society, nation, and religion.

From the above understanding, it can be concluded that education is a planned process to make students become human beings who develop broad knowledge, both for themselves and for others. In carrying out the education process the teacher is a very important guest star in the world of education with a teacher, a lot of knowledge is learned, so that it keeps people from being stupid to become intelligent humans for generations to come.

In the process of learning and teaching, it cannot be separated from the existence of teachers, without a teacher all learning materials will be difficult to understand, because the teacher is someone who has the most active role, in order to achieve the mission and vision of education, not only as a teacher, but the teacher has multiple roles function in education, for the smooth running of something that is planned and expected for students with the sole aim 
of educating the children of the Indonesian nation. In the learning and teaching process, the teacher is not just directing the learning material, but the teacher must be able to play a role in providing motivation. With this motivation, it can support the spirit of learning and can encourage students to achieve learning goals.

As stated in Law. RI NO. 20 of 2003 concerning National Education System in Article 3 which reads: National education functions to develop the capabilities and forms of character and dignified national civilization in the context of educating the nation's life so that they become human beings who believe, and are devoted to God Almighty, have noble character, are knowledgeable, capable, creative, independent, and become a democratic citizen.

With the above understanding, we can observe that a teacher must be creative and talented in teaching and learning, by directing and providing motivation in learning activities, both by providing motivation from various life experiences of a human being who never gives up from failure to achieve success in life, or with a system of directing students to provide motivation in the form of enthusiasm for learning and giving life direction to students regarding the regrets of human life who do not want to learn and always take their learning activities lightly in their youth.

Therefore, a teacher must provide direction in the form of motivation so that regret in old age never occurs to students in the present and in the future. And the teacher's efforts to provide motivation in learning activities, students will know the purpose of learning and make these learning resources for themselves very important and meaningful in their lives, so that students have various goals of their own and achieve their goals in an earnest way in study.

Oemar Hamalik mentions that every action is always due to motivation, the emergence of motivation because someone feels the need for something and because the action was directed to the achievement of certain goals as well. If the goal has been achieved then he will be satisfied, behavior that has given satisfaction to a need will tend to be repeated, so that he will be more and more stable.

There are educational psychologists who mention the mental strength that drives learning as motivation to learn, motivation is seen as a mental impulse that moves, and directs, human behavior, including learning behavior, in motivation there is activating, moving, channeling, and directing attitudes and individual learning.

When a teacher provides motivation in learning activities, it will be a big influence between teachers and students and with the motivation of course in the teaching and learning process there will be a desire and hope that activates and directs the attitude of a student to the path of success. Even though he has achieved success in life that is far beyond his teacher, both in terms of position, wealth, fame, or broad knowledge, then deep down he will remember how much he misses the motivator who always supported him to study in childhood, namely; a teacher who always sacrifices in difficulty in educating him from the swing to the grave, and in his little heart will be tucked in respect which is expressed in various forms, such as smiles, greetings, kissing hands, lowering his head, to giving certain gifts, not calculated from the billions of dollars spent but his infinite gratitude for a lifetime. This is one of the joys of a teacher, when he can still witness the success of his students in life. The respect of the students does not appear automatically but is actually built from the professional attitude and behavior displayed by the teacher when he is still on duty, providing the best service in education in the form of motivation to his students. 
If there is no motivation in teaching and learning activities, humans will really affect things that are very difficult to learn in the various materials taught by their teachers, especially for students will feel various complaints or various obstacles in learning that will cause boredom and boredom so that it will cause laziness and reluctance in learning. Likewise, without motivation, humans will affect failure in learning, and will affect in improving humans from lazy to diligent, from bored to fun, from naughty to obedient, from failure to success, and so on, all of which will be affected without motivation.

In the teaching and learning process, especially at the Dayah MUDI Putri Mesjid Raya Samalanga, Bireuen Regency, it is carried out in three schedules, namely the morning schedule (07:50 to $10: 30)$, the afternoon schedule at 13:50 to 10 minutes before Azan asr), and the evening schedule (19:30 to 23:30). And each class has three permanent teachers to teach which are divided into study hours, some are night teachers, morning teachers and afternoon teachers. Every teacher who teaches is obliged to teach students and must reach the limits of all learning materials that have been applied by the education curriculum section, in order to achieve the mission and vision of the curriculum section.

With the method that has been applied, but there are still many among the students with the lack of learning, lack of achievement, less active in the classroom, so that the influence of students on learning outcomes does not increase and even decreases greatly in various learning materials that have been applied in the field of education, especially in the classroom.

Seeing the various problems that were present, the lack of interest of students in learning with the teacher's efforts in providing motivation and its influence on learning outcomes for students to become human beings expected in the future. And in the teacher's efforts to improve student achievement to become successful and talented human beings, only for the nation and religion, the authors are very interested in researching the author's research on "The Role of Teachers as Motivators and Their Influence on Learning Outcomes (Analysis Study of Class 1D Santri at LPI Mudi Putri Mesjid Raya Samalanga, Bireuen Regency)"

\section{Review of Literature}

\subsection{Role}

The Big Indonesian Dictionary (KBBI) writes that: The word "peran" means "perangkat tingkah laku (a set of behaviors)" that are expected to be possessed by people who are domiciled in society. Role is the implementation of a person's rights and obligations according to his position. Roles determine what a person should do for society and what opportunities society gives him or her. For example, the scholars have a very large role in building the ummah.

What is meant here is the role of the teacher in teaching and learning. Wina Sanjaya mentions that one of the roles played by the teacher is as a guide and to be a good mentor, the teacher must have an understanding of the child he is being mentored. Meanwhile, regarding the role of subject teachers in guidance and counseling, subject teachers in approaching children must be human, religious, friendly, friendly, encouraging, concrete, honest, and genuine, understand and appreciate unconditionally.

Meanwhile, according to Siti Aisyah, the role of the teacher as the main component in the world of education, because teachers are required to be able to accompany and even surpass the development of science and technology that develops in the soul of children and today's society, with education as a system and a way to improve the quality of human life in 
all aspects of life in this world. The word role here is the teacher's role in increasing the motivation of students in the classroom to make students from lazy to diligent, from naughty to obedient, from stupid to smart and talented.

\subsection{Teacher}

According to the Big Indonesian Dictionary (KBBI) what is meant by a teacher is a person whose job (livelihood, profession) is teaching. Meanwhile, according to Suparlan, a teacher can be defined as a person whose duties are related to efforts to educate the nation's life in all its aspects, both spiritual and emotional, intellectual, physical, and other aspects. Then according to Muhaimin, the teacher is the person who bears the responsibility for guiding, he can also be said as an educator, the person who provides knowledge with the aim of educating and fostering the morals of students to become good people. The teacher's words here are human efforts in humanizing humans by directing paths in providing motivation in the classroom.

\subsection{Motivator}

Motivators are people who have a profession or livelihood from providing motivation to others. The provision of this motivation is usually through training, but it can also be through mentoring, coaching or counseling.

According to the Big Indonesian Dictionary (KBBI) motivator has two meanings:

a. People (stimulators) who cause motivation in others to do something: pusher: mover.

b. Officers appointed to provide information and motivation to prospective family planning acceptors. The motivator meant here is the teacher's role as a motivator.

According to Suparlan, the teacher's role as a motivator is related to the teacher's role as educator and supervisor, to increase high morale, students need to have high enthusiasm both within themselves (intrinsic) and from outside (extrinsic), which mainly comes from the teacher himself.

According to E. Mulyasa, the teacher as a motivator should be responsible for directing the good, must be an example, patient and full of understanding. Teachers must be able to cultivate self-discipline. The word motivator here is the role of the teacher in providing the much-needed motivation in various places of education, especially in teaching and learning activities the teacher must be able and creative in providing motivation and direction in the classroom, in order to make students able to support the spirit of learning and be passionate.

\subsection{Effect}

According to the Big Indonesian Dictionary, influence is a power that exists and arises from something (person or object) that helps shape a person's character, belief, or actions. Surakhmad stated that influence is a force that arises from an object or person and also an internal phenomenon that can change what is around him. The word change here is a change in increasing teacher motivation for students in learning activities which has always been a supporter of students' enthusiasm for the teacher's method regarding the teacher's role as a motivator.

\subsection{Learning Outcomes}

To provide knowledge about learning outcomes, it will be described first in terms of language. This understanding consists of two words "results" and "learning". In KBBI results have several meanings:

a. Something created by business, 
b. Income; acquisition; fruit. While learning is a change in behavior or responses caused by experience.

According to Dimyanti and Mudjiono learning is the origin of the word "ajar" which means instructions given to people to know. Teacher activities during teaching must provide encouragement (motivation) to students, so that the instructions that the teacher wants to convey during learning can be understood and implemented by students, in order to produce the desired learning outcomes, and achieve a lesson expected by both the teacher and the students.

\section{Research Methods}

The type of research method that researchers use in this study is qualitative methods. Qualitative research is research that is intended to understand phenomena about what is experienced by research subjects such as behavior, perceptions, motivations, actions and others, holistically and by means of descriptions in the form of words and language.

In this study, the qualitative research focuses more on a phenomenon that is selected and discussed in depth, namely in the form of a group of students and teachers. Based on this research, the researcher wants to describe in this study the role of the teacher as a motivator and its influence on the learning outcomes of grade 1d students at MUDI Putri Mesjid Raya Samalanga, Bireuen Regency by focusing on various kinds of learning motivation, caring, patience, creativity, humility and the commitment that must exist in a teacher in order to attract the attention of students.

This research is descriptive approach. This is a research that is directed to provide symptoms, facts, or events systematically and accurately in examining the status of a group of people, an object, condition or an event. Descriptive research is used to provide in-depth symptoms and facts in social life to provide a systematic, factual and accurate description of the facts, characteristics, and relationships between the phenomena being investigated.

This research is able to provide an in-depth understanding and interpretation of facts relevant to the phenomenological approach. This is an approach that is directed at trying to explain or reveal the meaning of concepts or phenomena of experience that are based on awareness that occurs in several individuals. This approach is carried out in a natural situation, so that there are no limits in interpreting or understanding the phenomenon under study and researchers are free to analyze the data they want to obtain.

\section{Result and Discussion}

\subsection{Teacher's Role as Motivator for Class 1D Santri at Dayah MUDI Putri Mesjid Raya Samalanga, Bireuen Regency}

To examine what the teacher's role is in trying to provide motivation that is still found among students who are lacking in learning, lack of achievement, less active in class, so that students' influence on learning outcomes does not increase and even decreases greatly in various learning materials that have been applied. in the field of education curriculum in order to achieve the mission and vision of education at Dayah MUDI Putri Mesjid Raya Samalanga, Bireuen Regency, especially in the classroom. 
First, the researcher interviewed the night teacher as a homeroom teacher for class 1d, namely Teungku Mariani M. Yakob answered in teaching and learning activities in the classroom, first of all learning to always be disciplined such as entering the local area on time, getting used to before learning to read the prayer, starting learning later continued to read Nazam Bait, then his first routine in teaching in the classroom, before starting to read the book always gives them the opportunity to repeat the previous learning materials and deposit some memorization material that has been applied in the curriculum section.

If outside the classroom, it is applied to them to be obliged to repeat to private teachers who have been applied in their respective caravans so that they are not left behind in exploring and understanding the material that has been taught and can increase student achievement and can facilitate students in taking the chess exam perfectly as has been implemented in the Dayah MUDI Putri Mesjid Raya Samalanga, Bireuen Regency.

In teaching and learning activities, he as a night teacher who works as homeroom teacher for grade $1 \mathrm{~d}$ is not only providing material, but must be able to provide millions of strong directions and motivations and always encourage them when they are bored in learning. In this study, the researcher also interviewed the morning teacher who teaches in class $1 \mathrm{~d}$ about how the teaching system is applied in the classroom so that students are always active in the classroom and to support students' learning enthusiasm, and how the teaching system is about students being lazy in learning.

Teungku Fathiah Nurdin as a morning teacher who teaches in grade 1d answered, before starting the learning materials, firstly abstain them, if one of them is absent other than sick, he will ask the class leader to visit the dormitory. the second is repeating past material and depositing daily memorization material that has been applied by the curriculum section, if you can't do it the first time, you are given advice in the form of advice not to repeat it, if the second time you can't do it again, you will be given a punishment in the form of standing under the hall. or punishments that can make students not repeat the same mistakes and with the punishments that have been applied, students will always try to be serious in repeating. Likewise in the application of daily rote deposits. On the sidelines of learning, I always give them the opportunity to ask questions about learning materials that are difficult to understand or understand.

And in the midst of learning he always pays attention to them, if one of them is bored or lazy in studying, he will try to entertain them in the form of advising them in the form of stories in the form of the history of the life of the Prophet, the companions of the Prophet, and telling the struggle of the life of the scholars in seeking knowledge that makes them touched or inspired and can use the story as a guide in their lives and mutual openness between teachers and students, both individually and in groups.

Thus, the application of internal teachers can support enthusiasm in their learning, and make them accustomed to discipline both inside and outside the classroom. In addition, the afternoon teacher researchers who teach in class $1 \mathrm{~d}$ regarding any methods of educating students from lazy to diligent, from naughty to good students and what forms of motivation are applied to educate naughty and lazy students both in class and outside class.

Teungku Fatahillah as the afternoon teacher who teaches in class $1 \mathrm{~d}$ he replied, in educating naughty students or lazy students in the first class he tried to teach patiently and not easily get angry, and always gave them attention and advised them when they always dissolved in mistakes in the form of words that are not polite, behave less politely and are 
always in violation.

And applying them to always be active in repeating, and getting used to asking questions about material that they don't understand, once a week he checks the notebooks of various materials that have been taught so that they get used to writing and make notes that are very useful in the future. Likewise, once every two days he tested them regarding the books they had studied, in order to find out the extent of their ability to study and understand the material that had been taught and to train themselves mentally so that they were always ready to take the chess test at Dayah.

In applying the method of teaching activities at night, morning and afternoon, more or less of them in the classroom are always serious about learning and carrying out what their teachers have implemented in the classroom. And more or less some of them never get bored and are always passionate about learning because in the classroom the teacher always creates a cheerful and fun atmosphere in the form of telling inspired and motivated stories and stories of the life of the Prophet. When outside the classroom they are always active in repeating to private teachers who have been determined by their respective caravans. And carry out the activities of the dayah as usual.

And Teungku Marhamah Hasby answered, in teaching and learning activities in the classroom, the teacher is not only providing learning material, but the teacher must be able to provide motivation when boredom always approaches students, when the teacher always provides learning material without any functions applied in learning objectives or directions in the form of motivation, many of which are found among students both inside and outside the classroom will feel bored in learning and even not interested and of course all the material that has been applied in the curriculum section will not work as expected.

In the application to increase the achievement of students or students in the classroom, we apply for them to be obliged to repeat to the private teacher we have provided in the curriculum section, if one of them is not present in taking attendance unless sick or going home, we will give a punishment in the form of objects that have been agreed upon by the curriculum. Likewise in the application of daily memorization deposits in the form of blank values to class teachers who teach at night or in the morning. so that we can train the students to be serious in memorizing and be able to improve more than the previous students. In an effort to achieve the mission and vision of education.

\subsection{The Influence of Teachers in Improving the Learning Outcomes of Class 1D Santri in Dayah MUDI Putri Mesjid Raya Samalanga, Bireuen Regency}

In the learning outcomes activities obtained, the achievement or not being achieved in the educational process, the expected learning outcomes are desired, depending on how the teacher system improves student learning outcomes so that they are more affective and quality and what methods are the teachers in developing learning materials so that they are not bored and always passionate in various situations and conditions that make them intelligent and accomplished human beings.

In this case, the researchers interviewed a student named Khairiana Tgk. Ismail, replied that if he did not focus on studying, the teacher always paid attention to him and asked him with an open heart then the teacher gave a good solution, to always be istiqamah in learning and believe that every bad thing comes from the jinn while good things come from angels. 
In addition, Scherly Susanti Kamaruddin replied, when he was always neglectful during study hours, the teacher always monitored him and paid attention to him, and always reminded him not to be negligent and lazy because being lazy or negligent will make us regret in the future, and being lazy and negligent. comes from the nature of stupid people who never want to aspire to step up to become intelligent and successful people. In addition, Noval Eliyana Djaminuddin, answered, when he is less optimistic about himself in other words he lacks confidence and is not sure he is serious in repeating, the teacher always convinces him, success and happiness lies in people who always believe in being serious in study.

According to Putri Humairah Tgk. Ibn Hajar, replied, when he was influenced by an immoral external environment and told his situation to the teacher then the teacher gave advice not to be influenced by the outside environment and western culture and always to be yourself without making yourself into someone else because being yourself better than being someone else, stay grateful with the destiny of Allah who has given us to be the best.

According to Siti Irawati Jailani, answering, when a feeling of lack of enthusiasm always approaches the soul and is accompanied by a sense of boredom in learning, the teacher always pays attention to it, and provides entertainment in the form of historical stories that are full of inspiration for her and for her friends to make it always learn from an experience to make it from lazy to diligent.

According to Asra Maqhfirah Ridwan replied, his influence during his time at the dayah was due to lack of money or lack of spending for both his own needs and other needs that would not last long to stay in the dayah, thus the teacher always paid attention to him like a mother's attention to her own child and always encouraging him not to give up easily in studying.

According to Munadiatul Asra Dailami, what he is experiencing now and often doesn't focus on his studies is that he lacks parental support to teach the Koran to become a santriwati instead of being a student in a college they are proud of, thus the teacher provides a solution for him, when parents are happier seeing their children go to college. instead of reading the Koran, thus we as children should never hate parents but prove to parents that we can be children who make them proud of their polite and Muslim attitude, behavior, and dress modestly and Muslim.

According to Nanda Nasratun, Nisa Anwar replied, when the soul is not istiqamah in learning goals, and it is not comfortable to live in the dayah, the teacher always gives him advice and gives him a shadow of life so that he is not like outsiders who are uneducated and always immoral during his life.

The results of the researcher's observation that in the classroom the teacher always pays attention to them both in class and personally and always provides the best solution to them when facing various difficulties or problems and they always try to live it, then in class they are still active as usual not immediately took action not to recite the Koran anymore but they still listened to the advice and solutions of their teachers. 


\section{Conclusion}

Based on the description of the discussion, data analysis and interview results, the conclusions can be formulated as follows:

1. In guarding learning activities, teachers are not just directing various learning materials as has been implemented by the education curriculum section at Dayah MUDI Putri Mesjid Raya Samalanga, Bireuen Regency, but the teacher's job is to always provide motivation in learning objectives, and provide advice that can soften the hearts of students. students from naughty to obedient, from lazy to diligent, from stupid to intelligent, from failure to success. In this way, the achievement of the educational goals expected by the previous successors to become a human generation that is useful for religion and the nation.

2. The factors that influence students' learning outcomes both inside and outside the classroom, are not consistent in learning goals, are influenced by the external environment, are always negligent in learning and feel lazy that cannot be controlled by themselves, do not focus on learning goals and lack economy or lack of funds both for their own needs and for other needs that will not last long in the study period, and are not enthusiastic about learning because of lack of support from family. Even so, keep trying to learn by way of various directions, advice and motivation from the teacher. In order to make support for enthusiasm in learning, and be directed in the results of learning objectives.

\section{References}

Abdul majid dan Dian andayani. Pedidikan karakter dalam perspektif Islam, Bandung: Insan Cita Utama, 2010.

Abdullah Nashih Ulwan, Pendidikan Anak dalam Islam, Jakarta: Pustaka Amani, 2007.

Ahmad Subandi dan Salma Fadhlullah, Agar Tidak Salah Mendidik Anak, Jakarta: Alhuda, 2006.

Ahmad Sunarto, Tarjamah Shahih Bukhari, Semarang: Asy-Syifa, 1993.

Akdon dan Hadi, Aplikasi Statistika dan Metode Penelitian untuk Administrasi dan Manajemen, Bandung: Dewa Ruchi, 2005.

Alisuf Sabri, Ilmu Pendidikan, Jakarta: Pedoman Ilmu Jaya, 1999. Alwisol, Psikologi Kepribadian, Malang: UMM Press, 2006.

Aziz Mushoffa, Aku Anak Hebat Bukan Anak Nakal, Jogjakarta: DIVA Press, 2009.

Chacah, Pendidikan Agama Dalam Pembentukan Karakter Anaka, (Online): http:// ryzchacha. blogspot.co. id/2013/10/ pendidikan-agama-dalam-pembentukan.html.

Departemen Agama RI, Al-Qur'an dan Terjemah, Bandung : Jumanatul 'ali-ART, 2005.

Depdiknas, Kamus Besar Bahasa Indonesia, Jakarta: Gramedia Pustaka Utama, 2008. Depdiknas, Tesaurus Bahasa Indonesia, Jakarta: Pusat Bahasa, 2008.

Djam'an Satori, Metode Penelitian Kualitatif (Matakuliah Analisis. Penelitian Kualitatif), Bandung: Sekolah Pascasarjana Universitas, 2007.

Doni Koesoema A, Pendidikan Karakter Strategi Mendidik Anak di Zaman Global, Jakarta: Garsindo, 2010.

Fatchul Mu’in. Pedidikan karakter kontruksi teoritik dan praktek, Yogyakarta: Ar-Ruzz Media, 2011.

Herimanto, Ilmu Sosial Dan Budaya Dasar, Jakarta: Bumi Aksara, 2010. Hery noer aly, Watak Pendidikan Islam, Jakarta: Friska Agung Insani, 2003.

Hildawati, "Strategi Guru Pendidikan Agama Islam Dalam Pembinaan Akhlak Dan Moral Siswa", Skripsi pada Fakultas Tarbiyah STAI Al-Aziziyah Samalanga, 2012.

Husain Mazhahiri, Pintar Mendidik Anak (Panduan Lengkap Bagi Orang Tua, Guru, dan Masyarakat Berdasarkan Ajaran Islam), Jakarta: Lentera Basritama, 1999.

Kartini Kartono, Peranan Keluarga Memandu Anak, Sari Psikologi Terapan, Jakarta: Rajawali Press, 1982. 
Lexy J, Moleong, Metodologi Penelitian Kualitatif, Bandung: Remaja Rosdakarya Offset, 2007.

Lexy J. moleong, M.A, Metodologi Penelitian Kualitatif, Bandung: Remaja Rosdakarya, 2002.

M. Atho' Mudzar, Menuju Pendidikan Keagamaan dalam Sosial, Cirebon: Pusat Penelitian dan Pengembangan Pendidikan Islam, 2006.

Margono Slamet, Pertumbuhan dan Peranan Lembaga Swadaya. Masyarakat dalam Pembangunan, Solo: Ramadhani, 1995.

Maryana, Peranan Orang Tua Dalam Meningkatkan Pendidikan Agama Islam Bagi Anak (Studi Kasus di Gampong Garot Kecamatan Pandrah Kabupaten Bireuen), Skripsi pada Fakultas Tarbiyah STAI Al-Aziziyah Samalanga, 2014.

Megawangi, Ratna, Pendidikan Karakter untuk Membangun Masyarakat Madan, Jakarta: IPPK Indonesia Heritage Foundation, 2003.

Melly Latifah, Tumbuh Kembang Anak, (Online), http://tumbuh-kembang-anak. blogspot. co. id/2008/03/ pendahuluan-saat-di- layar-televisi- kita.html.

Miftah Toha, Perilaku Organisasi Konsep Dasar dan Aplikasinya, Jakarta: Raja Grafindo Persada, 2003.

Mudjijono, Strategi Belajar Mengajar, Jakarta: Depdikbud, 1999.

Muhammad Chabib Thoha, Kapita Selekta Pendidikan Islam, Yogyakarta: Pustaka Belajar, 1996.

Munawar Sholeh, Politik pendidikan, Jakarta: Institute For Public Education (IPE), 2005. 